\title{
Efficacy of pegylated interferon plus ribavirin in combination with corticosteroid for two cases of combined hepatitis $\mathbf{C}$ and autoimmune hepatitis
}

\author{
Satoshi Oeda - Toshihiko Mizuta $\cdot$ Hiroshi Isoda • Takuya Kuwashiro • \\ Noriko Oza · Shinji Iwane $\cdot$ Hirokazu Takahashi $\cdot$ Yasunori Kawaguchi $\cdot$ \\ Yuichiro Eguchi $\cdot$ Shuji Toda $\cdot$ Iwata Ozaki $\cdot$ Keizo Anzai $\cdot$ Kazuma Fujimoto
}

Received: 23 January 2012 / Accepted: 6 March 2012/Published online: 28 March 2012

(c) The Author(s) 2012. This article is published with open access at Springerlink.com

\begin{abstract}
The treatment strategy for cases of combined autoimmune hepatitis (AIH) and chronic hepatitis $\mathrm{C}(\mathrm{CHC})$ has not yet been established. A 47-year-old woman and a 53-year-old-woman were hospitalized for treatment of CHC. Ultrasonography and histological findings revealed that their liver was not cirrhotic but did have chronic damage. The histological findings of both patients were suggestive of AIH. The patients were systematically treated with pegylated interferon-alpha $2 \mathrm{~b}$ plus ribavirin which was preceded by and combined with corticosteroid (CS), and showed sustained virological responses and normal liver function. Although these two patients with combined $\mathrm{AIH}$ and CHC were successfully treated with this regimen, careful attention to exacerbation of hepatic inflammation is needed because hepatitis $\mathrm{C}$ viral load was increased due to immunosuppression during CS treatment.
\end{abstract}

Keywords Autoimmune hepatitis - Chronic hepatitis C . Interferon · Ribavirin · Corticosteroid

\section{Introduction}

Hepatitis $\mathrm{C}$ virus (HCV) infection is known to be associated with various autoimmune diseases, such as

S. Oeda $\cdot$ T. Mizuta $(\bowtie) \cdot$ H. Isoda $\cdot$ T. Kuwashiro $\cdot$ N. Oza $\cdot$

S. Iwane - H. Takahashi - Y. Kawaguchi - Y. Eguchi - I. Ozaki ·

K. Anzai · K. Fujimoto

Department of Internal Medicine, Saga Medical School,

5-1-1 Nabeshima, Saga 849-8501, Japan

e-mail: mizutat@cc.saga-u.ac.jp

S. Toda

Department of Pathology, Saga Medical School,

5-1-1 Nabeshima, Saga 849-8501, Japan autoimmune hepatitis (AIH), Sjögren's syndrome, rheumatoid arthritis and autoimmune thyroid disorders [1]. Among AIH patients, it has been reported that at least $10 \%$ were infected with HCV in Japan [2]. Although corticosteroid (CS) therapy has been established as effective for AIH [3-5], there is concern about the possible increase in $\mathrm{HCV}$ caused by the immunosuppressive effect of CS in $\mathrm{HCV}$-infected $\mathrm{AIH}$ patients. In contrast, interferon (IFN) administration, which is effective for chronic hepatitis $\mathrm{C}(\mathrm{CHC})$, has been reported to initiate acute exacerbation of AIH [6], and sometimes fulminant hepatic failure $[7,8]$. Owing to these discordant treatment options for AIH and $\mathrm{CHC}$, the treatment decision for patients with both of these hepatic diseases represents a dilemma.

Here we report two patients with combined AIH and CHC who showed favorable outcomes with pegylated IFN (PEG-IFN) plus ribavirin (RBV) therapy which was preceded by and combined with CS administration.

\section{Case reports}

Case 1

A 47-year-old woman (height $153.3 \mathrm{~cm}$, weight $64.5 \mathrm{~kg}$ ) was referred to our hospital for treatment of $\mathrm{CHC}$ in August 2006. Although she had received IFN therapy 5 years previously, eradication of $\mathrm{HCV}$ had not been achieved, and her serum levels of transaminases during the therapy had been higher than baseline.

She was not a habitual drinker, and there was no history of blood transfusion, drug abuse or tattoos. There were no abnormal findings in her physical examination. Blood tests showed that the alanine aminotransferase (ALT) level was $97 \mathrm{IU} / \mathrm{L}$, immunoglobulin (Ig) G concentration was 
$3457 \mathrm{mg} / \mathrm{dL}$, anti-nuclear antibody (ANA) titer was 1:40, liver-kidney microsomal antibody-1 (LKM-1) was negative, HCV genotype was $2 \mathrm{a}$ and viral load was $2700 \mathrm{KIU} /$ $\mathrm{mL}$ (Table 1). HLA typing showed DR4. To distinguish between AIH and CHC, a liver biopsy was carried out under laparoscopy. Although characteristic laparoscopic findings for AIH of multilobular and ecchymotic red macula, extensive recess, furrowed recess and rough and large tuber were not seen; microscopic findings showed considerable infiltration of plasma cells in portal areas and severe interface hepatitis, which are uncommon in $\mathrm{CHC}$ (Fig. 1). Therefore, we determined that the main cause of her hepatic disorder was $\mathrm{AIH}$, although the diagnostic score according to the International Autoimmune Hepatitis Group (IAIHG) in 1999 [9] was 12 points, defined as 'probable' for AIH.

We started $30 \mathrm{mg} /$ day prednisolone (PSL) administration in October 2006. Although the IgG level gradually decreased after initiation of PSL, the ALT level remained unchanged. Serum HCV load increased to $4800 \mathrm{KIU} / \mathrm{mL}$ during PSL administration. After 6 weeks of PSL (ALT $101 \mathrm{IU} / \mathrm{L}$, IgG
$2008 \mathrm{mg} / \mathrm{dL}$ ), a weekly subcutaneous injection of $100 \mu \mathrm{g}$ PEG-IFN-alpha-2b and daily oral administration of $800 \mathrm{mg}$ RBV were started in combination with $20 \mathrm{mg} /$ day PSL. The ALT level decreased gradually after starting PEG-IFN plus RBV therapy, and HCV RNA disappeared from her serum at week 8 of PEG-IFN plus RBV therapy. Subsequently, a sustained virological response (SVR) was achieved by PEG-IFN plus RBV therapy for 24 weeks. PSL was continued for 4 months after cessation of PEG-IFN plus RBV, and then withdrawn because ALT and IgG levels remained continuously normal (ALT $13 \mathrm{IU} / \mathrm{L}, \mathrm{IgG} 1472 \mathrm{mg} / \mathrm{dL}$ at the end of PSL administration). From the end of the treatment to the present time, her serum ALT and IgG levels have been within the normal ranges for 3 years without any medication (Fig. 2).

\section{Case 2}

Case 2 was a 53-year-old woman (height $159 \mathrm{~cm}$, weight $56.6 \mathrm{~kg}$ ). She was diagnosed with $\mathrm{CHC}$ at 39 years of age, but had not taken any medication because of low serum
Table 1 Laboratory data on admission (Case 1)

\begin{tabular}{llllll}
\hline WBC & $4600 / \mu \mathrm{L}$ & Total protein & $8.2 \mathrm{~g} / \mathrm{dL}$ & IgG & $3457 \mathrm{mg} / \mathrm{dL}$ \\
$\mathrm{RBC}$ & $434 \times 10^{4} / \mu \mathrm{L}$ & Albumin & $3.8 \mathrm{~g} / \mathrm{dL}$ & IgA & $299 \mathrm{mg} / \mathrm{dL}$ \\
$\mathrm{Hb}$ & $13.1 \mathrm{~g} / \mathrm{dL}$ & $\gamma$-globulin & $31.9 \%$ & IgM & $47 \mathrm{mg} / \mathrm{dL}$ \\
$\mathrm{Ht}$ & $39.4 \%$ & AST & $82 \mathrm{IU} / \mathrm{L}$ & ANA & 40 times \\
Platelet & $14.7 \times 10^{4} / \mu \mathrm{L}$ & ALT & $97 \mathrm{IU} / \mathrm{L}$ & ASMA & $(-)$ \\
& & LDH & $226 \mathrm{IU} / \mathrm{L}$ & LKM-1 Ab & $(-)$ \\
& & ALP & $225 \mathrm{IU} / \mathrm{L}$ & AMA & $(-)$ \\
& & $\gamma$ GTP & $48 \mathrm{IU} / \mathrm{L}$ & HBs Ag & $(-)$ \\
& & Total bilirubin & $0.7 \mathrm{mg} / \mathrm{dL}$ & HBc Ab & $(-)$ \\
& & Cholinesterase & $266 \mathrm{IU} / \mathrm{L}$ & HCV-RNA & $2700 \mathrm{KIU} / \mathrm{mL}$ \\
& & & & Genotype & $2 \mathrm{a}$ \\
& & & & & \\
\end{tabular}
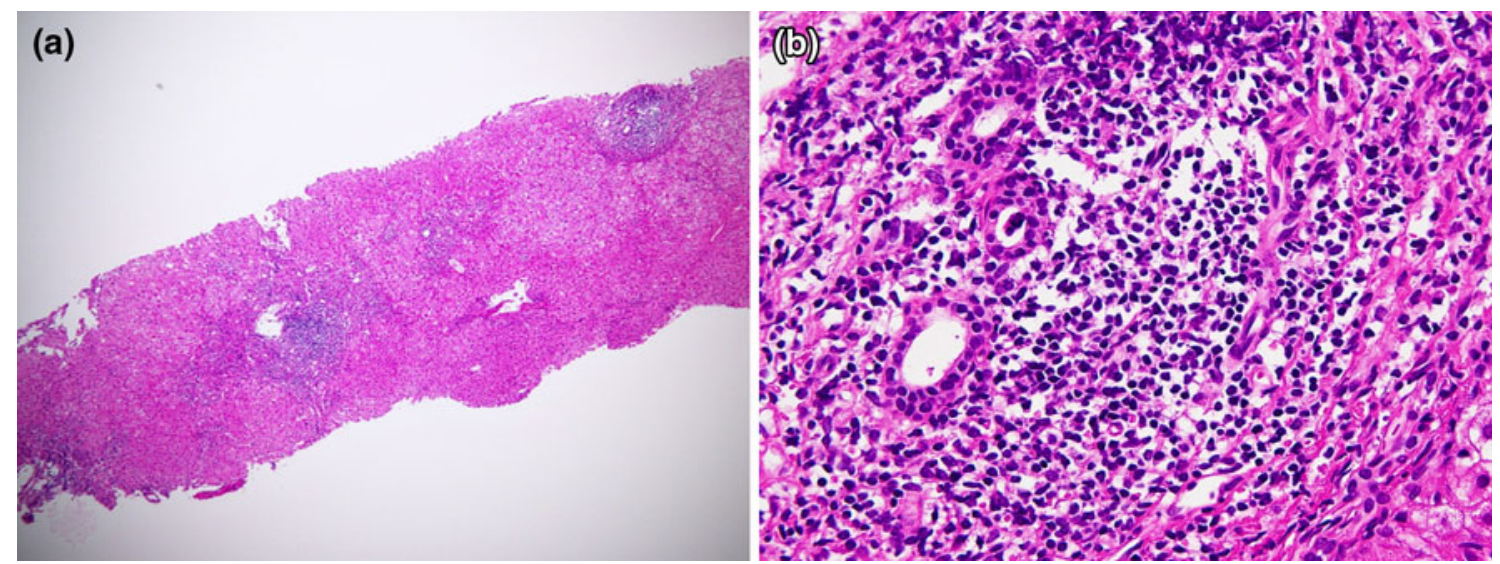

Fig. 1 Histological findings of Case 1 show considerable infiltration of plasma cells in portal areas and severe interface hepatitis. a H\&E $\times 40$, b $\mathrm{H} \& \mathrm{E} \times 400$ 
ALT levels. Symptoms of dry eye and mouth appeared in January 2008, and she was diagnosed with Sjögren's syndrome and mixed connective tissue disease based on the symptoms and serological tests, by a specialist in collagen diseases. Her hepatic function worsened after oral administration of pilocarpine hydrochloride, therefore, she was referred to our department.

She had a history of transfusion of blood coagulation factors during childbirth. Laboratory tests showed that theALT level was $128 \mathrm{IU} / \mathrm{L}$, IgG level was $1933 \mathrm{mg} / \mathrm{dL}$, ANA titer was 1:1280, LKM-1 was negative, HLA typing showed DR9 and DR15, HCV genotype was $1 \mathrm{~b}$ and viral load was $3.3 \log \mathrm{IU} / \mathrm{mL}$ (Table 2). Histological findings of a liver biopsy specimen showed moderate infiltration of lymphocytes and plasma cells in portal areas, interface hepatitis and rosette formation, which are typical $\mathrm{AIH}$ characteristics
(Fig. 3). Although the score according to the simplified criteria of AIH (IAIHG 2008) [10] was 6 points, which means 'probable' for AIH, we judged that her hepatic disorder was mainly caused by AIH, similar to Case 1 .

After starting oral administration of $40 \mathrm{mg}$ PSL $(0.7 \mathrm{mg} / \mathrm{kg})$ in February 2009, her ALT and IgG levels immediately decreased and became normalized. Serum HCV load increased to $5.6 \mathrm{log}$ IU/mL during PSL administration. After PSL administration for 13 weeks, with a gradual decrease in dose, a weekly subcutaneous injection of $80 \mu \mathrm{g}$ PEG-IFN-alpha-2b and daily oral $600 \mathrm{mg}$ RBV were started in combination with $20 \mathrm{mg} /$ day PSL. HCV RNA disappeared from her serum at week 8 of PEG-IFN plus RBV therapy, and an SVR was achieved by continuing the treatment for 48 weeks. After the end of the PEG-IFN plus RBV therapy, PSL dose was gradually decreased and
Fig. 2 Clinical course of Case 1

Table 2 Laboratory data on admission (Case 2)

ANA anti-nuclear antibody, ASMA anti-smooth muscle antibody, LKM-1 Ab liverkidney microsomal antibodies type $1, A M A$ antimitochondrial antibody

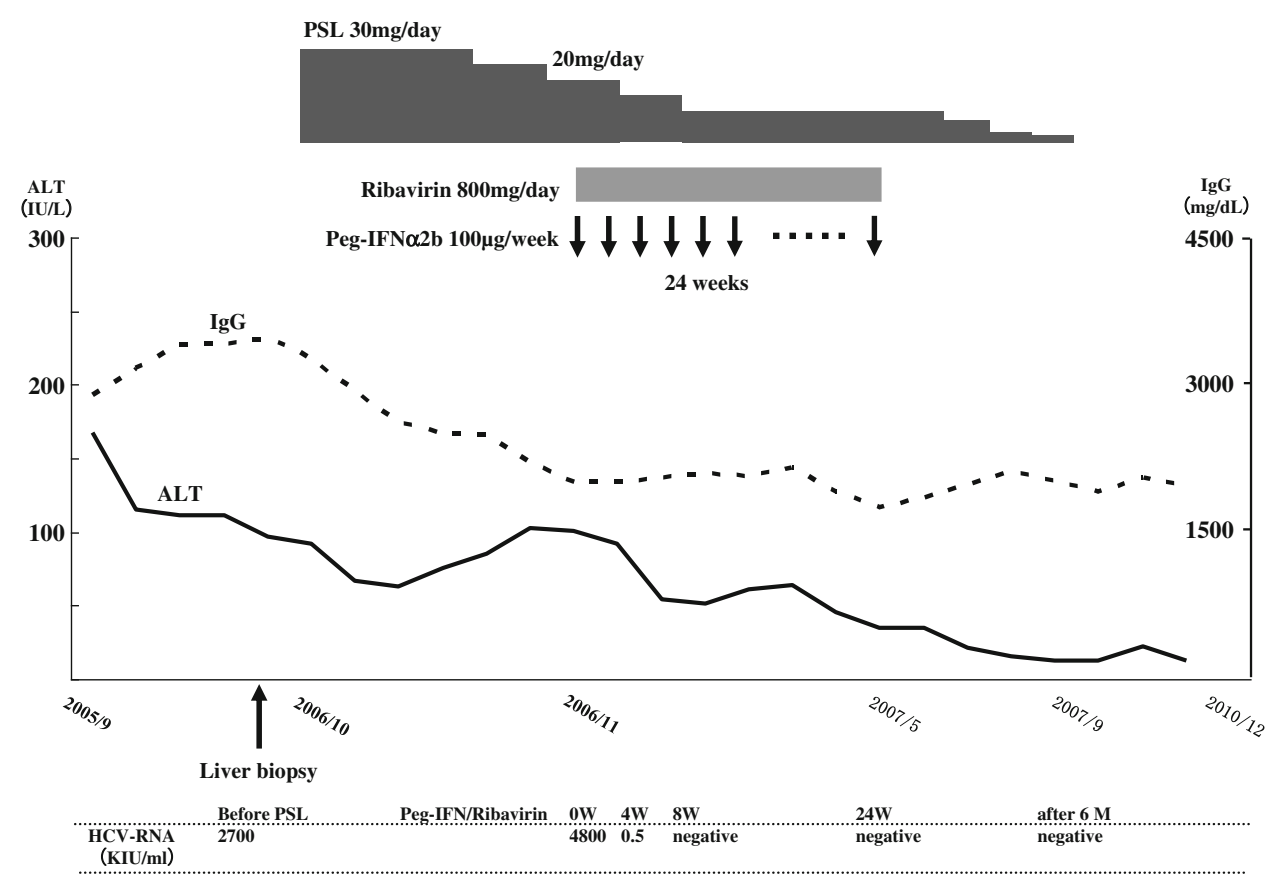

\begin{tabular}{llllll}
\hline WBC & $3600 / \mu \mathrm{L}$ & TP & $7.3 \mathrm{~g} / \mathrm{dL}$ & IgG & $1933 \mathrm{mg} / \mathrm{dL}$ \\
$\mathrm{RBC}$ & $463 \times 10^{4} / \mu \mathrm{L}$ & Albumin & $3.9 \mathrm{~g} / \mathrm{dL}$ & IgA & $322 \mathrm{mg} / \mathrm{dL}$ \\
$\mathrm{Hb}$ & $13.5 \mathrm{~g} / \mathrm{dL}$ & $\gamma$-globulin & $25.5 \%$ & IgM & $156 \mathrm{mg} / \mathrm{dL}$ \\
$\mathrm{Ht}$ & $40.4 \%$ & AST & $108 \mathrm{IU} / \mathrm{L}$ & ANA & $1280 \mathrm{times}$ \\
Platelet & $15.1 \times 10^{4} / \mu \mathrm{L}$ & ALT & $128 \mathrm{IU} / \mathrm{L}$ & ASMA & $(-)$ \\
& & LDH & $269 \mathrm{IU} / \mathrm{L}$ & LKM-1 Ab & $(-)$ \\
& & ALP & $169 \mathrm{IU} / \mathrm{L}$ & AMA & $(-)$ \\
& & & $85 \mathrm{IU} / \mathrm{L}$ & HBs Ag & $(-)$ \\
& & Total bilirubin & $1.3 \mathrm{mg} / \mathrm{dL}$ & HBc Ab & $(+)$ \\
& & Cholinesterase & $290 \mathrm{IU} / \mathrm{L}$ & HBV-DNA & $(-)$ \\
& & & HCV-RNA & $3.3 \log \mathrm{IU} / \mathrm{mL}$ \\
& & & Genotype & $1 \mathrm{~b}$ \\
& & & & HLA-DR & 9,15 \\
\hline
\end{tabular}



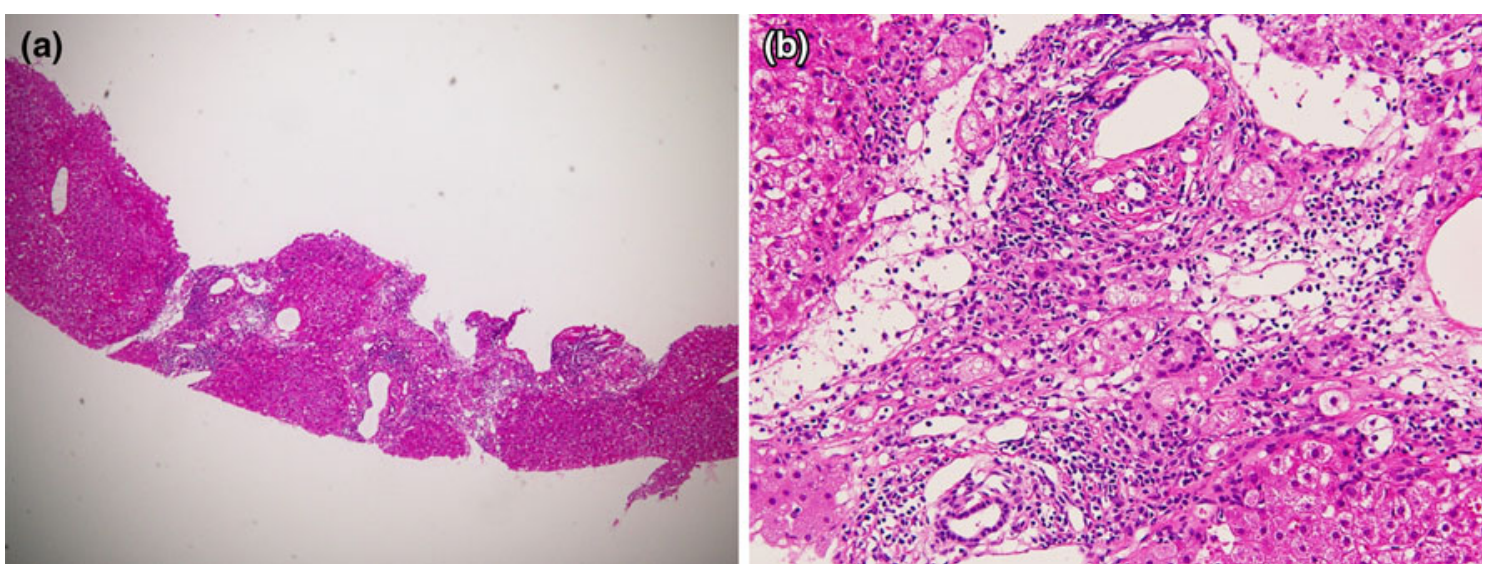

Fig. 3 Histological findings of Case 2 show moderate infiltration of lymphocytes and plasma cells in portal areas, interface hepatitis and rosette formation. a $\mathrm{H} \& \mathrm{E} \times 40, \mathbf{b} \mathrm{H} \& \mathrm{E} \times 400$

Fig. 4 Clinical course of Case

2

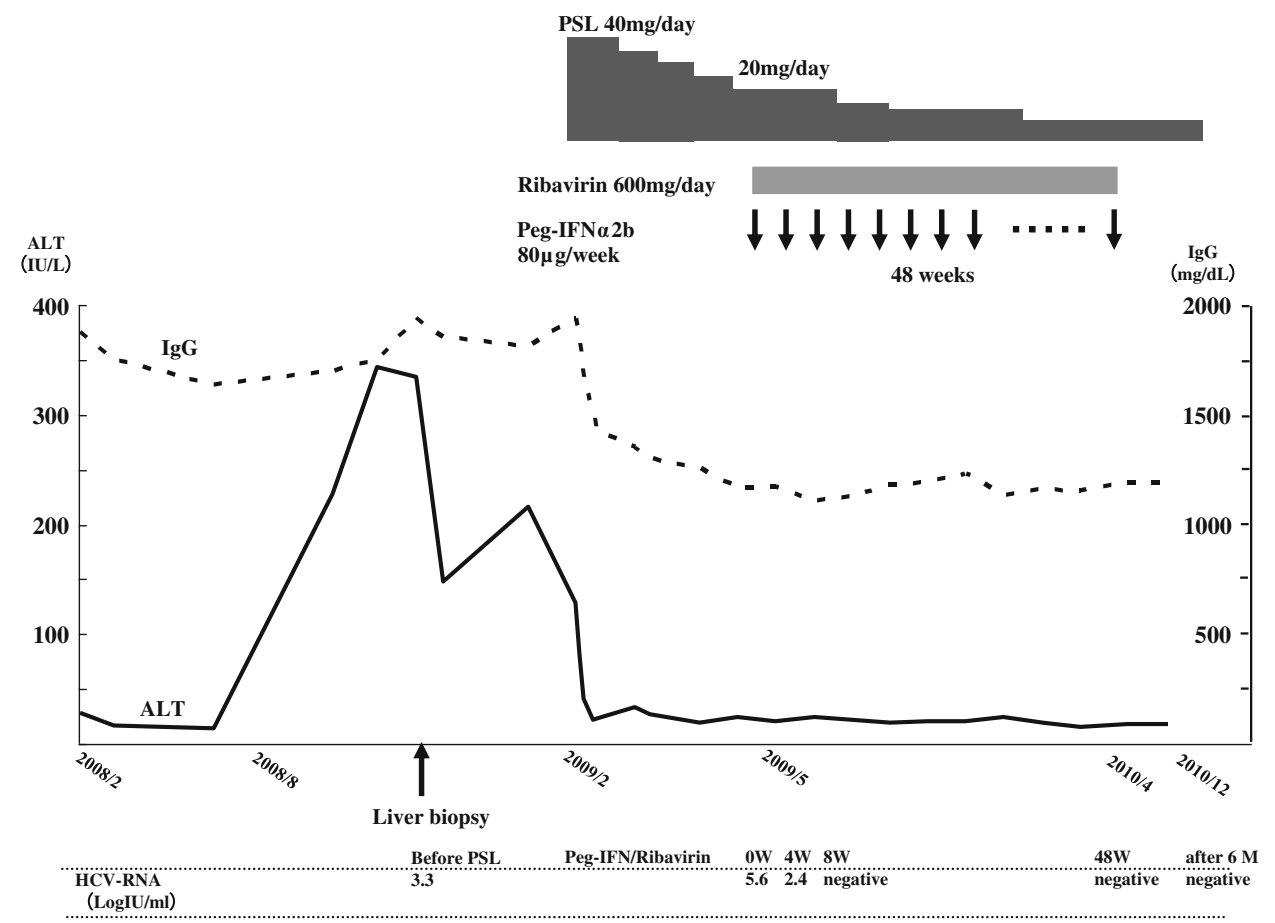

The most important issue in this approach is how to judge whether the autoimmunity is associated with hepatic inflammation in patients with $\mathrm{HCV}$ infection.

CHC patients sometimes become positive for autoantibodies such as ANA, therefore, it is difficult to distinguish serologically between simple $\mathrm{CHC}$ and $\mathrm{CHC}$ combined with AIH. A variety of type $2 \mathrm{AIH}$, which is characterized by anti-LKM-1 antibodies in the serum, has been reported with HCV-associated AIH [11]. However, the positivity rate of anti-LKM-1 antibodies in Japanese CHC patients is low [12], and our two cases were actually both negative.

There are some reports indicating the importance of histological manifestations such as severe piecemeal 
necrosis, lobular hepatitis, multinucleated giant cells, and moderate or severe infiltration of plasma cells, which are microscopic characteristics of $\mathrm{AIH}$, to distinguish $\mathrm{CHC}$ accompanied with AIH from simple CHC [13].

We diagnosed CHC combined with AIH based on changes in the level of ALT during previous IFN treatment and histological findings in Case 1, and on other accompanying autoimmune diseases and histological findings in Case 2.

However, the treatment strategy for combined $\mathrm{AIH} / \mathrm{HCV}$ has not yet been established. It is known that IFN often induces acute exacerbation of $\mathrm{AIH}$, and occasionally fulminant hepatic failure [6-8], therefore, many reports have recommended CS therapy for these patients $[14,15]$. In contrast, there are some reports showing that IFN therapy is more effective than CS, even in combined AIH/CHC [16]. Petersen-Benz et al. [17] reported successful treatment of a case with AIH/CHC overlap syndrome. First, they treated AIH with CS for several years, and then switched to IFN plus $\mathrm{RBV}$ therapy for $\mathrm{CHC}$, and achieved $\mathrm{HCV}$ eradication. However, readministration of CS was required to inhibit hepatic inflammation in this case. Therefore, we planned pretreatment with CS and subsequent IFN plus RBV therapy combined with continued CS for our two cases. PEG-IFN plus RBV therapy was started at 6 weeks of CS treatment in Case 1 versus at 13 weeks in Case 2 because the ALT level did not decrease steadily with CS administration in Case 1. As a result, favorable viral eradication was achieved without aggravation of hepatic inflammation in both cases.

Careful attention to viral breakthrough caused by the immunosuppressive effect of CS is required. Indeed, HCV load increased during CS administration in both of our cases. Therefore, when this therapeutic regimen is administered, it is necessary to monitor the ALT level closely until start of antiviral therapy, so as not to miss any exacerbation of hepatic inflammation.

Judging from the changes in IgG and ALT levels during CS treatment, it is speculated that the hepatic inflammation in Case 1 was caused by both HCV and autoimmunity, whereas that in Case 2 was mainly caused by AIH. Therefore, after termination of IFN plus RBV therapy, we attempted to stop CS treatment in Case 1, but continued a low dose PSL in Case 2.

In conclusion, although antiviral therapy combined with CS needs to be carefully applied, it may represent a worthwhile treatment for CHC patients with clinical and histological characteristics of AIH.

Conflict of interest The authors declare that they have no conflict of interest.

Open Access This article is distributed under the terms of the Creative Commons Attribution License which permits any use, distribution, and reproduction in any medium, provided the original author(s) and the source are credited.

\section{References}

1. Jadali Z, Alavian SM. Autoimmune diseases co-existing with hepatitis C virus infection. Iran J Allergy Asthma Immunol. 2010; 9:191-206.

2. Toda G, Zeniya M, Watanabe F, Imawari M, Kiyosawa K, Nishioka $\mathrm{M}$, et al. Present status of autoimmune hepatitis in Japan-correlating the characteristics with international criteria in an area with a high rate of HCV infection. Japanese National Study Group of Autoimmune Hepatitis. J Hepatol. 1997;26:1207-12.

3. Cook GC, Mulligan R, Sherlock S. Controlled prospective trial of corticosteroid therapy in active chronic hepatitis. QJ Med. 1971; 40:159-85.

4. Soloway RD, Summerskill WH, Baggenstoss AH, Geall MG, Gitnićk GL, Elveback IR, et al. Clinical, biochemical, and histological remission of severe chronic active liver disease: a controlled study of treatments and early prognosis. Gastroenterology. 1972;63:820-33.

5. Murray-Lyon IM, Stern RB, Williams R. Controlled trial of prednisone and azathioprine in active chronic hepatitis. Lancet. 1973;1:735-7.

6. Shindo M, Di Bisceglie AM, Hoofnagle JH. Acute exacerbation of liver disease during interferon alfa therapy for chronic hepatitis C. Gastroenterology. 1992;102:1406-8.

7. Kogure T, Ueno Y, Fukushima K, Nagasaki F, Inoue J, Kakazu E, et al. Fulminant hepatic failure in a case of autoimmune hepatitis in hepatitis $\mathrm{C}$ during peg-interferon-alpha $2 \mathrm{~b}$ plus ribavirin treatment. World J Gastroenterol. 2007;13:4394-7.

8. Coriat R, Podevin P. Fulminant autoimmune hepatitis after successful interferon treatment in an HIV-HCV co-infected patient. Int J STD AIDS. 2008;19:208-10.

9. Alvarez F, Berg PA, Bianchi FB, Bianchi L, Burroughs AK, Cancado EL, et al. International Autoimmune Hepatitis Group Report: review of criteria for diagnosis of autoimmune hepatitis. J Hepatol. 1999;31:929-38.

10. Hennes EM, Zeniya M, Czaja AJ, Parés A, Dalekos GN, Krawitt EL, et al. International Autoimmune Hepatitis Group. Simplified criteria for the diagnosis of autoimmune hepatitis. Hepatology. 2008;48:169-76.

11. Bai L, Lu HY, Feng ZR, Yu M, Li WG, Gong WB, et al. Detection and the production mechanism of antinuclear antibodies (ANA) and anti-liver/kidney microsomal type 1 antibodies (anti-LKM1) in patients with chronic hepatitis C. Zhonghua Shi Yan He Lin Chuang Bing Du Xue Za Zhi. 2009;23:278-81.

12. Nishioka M, Morshed SA, Kono K, Himoto T, Parveen S, Arima $\mathrm{K}$, et al. Frequency and significance of antibodies to P450IID6 protein in Japanese patients with chronic hepatitis C. J Hepatol. 1997;26:992-1000.

13. Carpenter HA, Czaja AJ. The role of histologic evaluation in the diagnosis and management of autoimmune hepatitis and its variants. Clin Liver Dis. 2002;6:685-705.

14. Schiano TD, Te HS, Thomas RM, Hussain H, Bond K, Black M. Results of steroid-based therapy for the hepatitis C-autoimmune hepatitis overlap syndrome. Am J Gastroenterol. 2001;96:2984-91.

15. Ballary S, Schiano T, Hartman G, Black M. Chronic hepatitis with combined features on autoimmune chronic hepatitis and chronic hepatitis C: favorable response to predonisone and azathioprine. Ann Intern Med. 1995;123:32-4.

16. Magrin S, Craxi A, Fabiano C, Fiorentino G, Almasio P, Palazzo $\mathrm{U}$, et al. Hepatitis C virus replication in 'autoimmune' chronic hepatitis. J Hepatol. 1991;13:364-7.

17. Petersen-Benz C, Kasper HU, Dries V, Goeser T. Differential efficacy of corticosteroids and interferon in a patient with chronic hepatitis C-autoimmune hepatitis overlap syndrome. Clin Gastroenterol Hepatol. 2004;2:440-3. 